\title{
Mobile Bagging System sebagai Solusi Pengemasan Hasil Pertanian
}

\author{
Bachtera Indarto, ${ }^{*}$ Didiek Basuki Rahmat, Hasto Sunarno, dan Andika Yulianto \\ Jurusan Fisika, Fakultas Matematika dan Ilmu Pengetahuan Alam, \\ Institut Teknologi Sepuluh Nopember (ITS), Kampus ITS Sukolilo, Surabaya 60111
}

\begin{abstract}
Intisari
Telah dilakukan penelitian tentang penerapan sensor massa sebagai sarana untuk pengemasan hasil pertanian. Penelitian dilakukan dengan membuat rangka mekanik dari alat pengemasan dengan weighing indikator sebagai kontroller dari sensor massa. Sensor massa yang digunakan adalah load cell tipe batang dengan kapasitas maksimum $20 \mathrm{~kg}$. Dari data diperoleh jumlah pengemasan tiap bahan uji berbeda-beda. Beras dengan kemasan $2 \mathrm{~kg}$ mampu mengemas sebanyak 17 kemasan/menit, kedelai dan jagung masing-masing menghasilkan $10 \mathrm{ke}-$ masan /menit dan 8 kemasan/menit. Untuk kemasan $3 \mathrm{~kg}$, beras mampu mengemas $13 \mathrm{kemasan} / \mathrm{menit}$, kedelai 8 kemasan/menit dan jagung 6 kemasan/menit.
\end{abstract}

\begin{abstract}
A research on application of mass sensors as a means for packaging agricultural produces has been done. The study was conducted by making the mechanical framework of the packaging tools by weighing indicator as controller of the mass sensor. Mass sensor which used is a rod-type load cell with a maximum capacity of 20 $\mathrm{kg}$. From the data was obtained the amount of packing materials for each different test. $2 \mathrm{~kg}$ pack of rice is able to package a total of 17 packs / min, soybean and corn can produce 10 packing / min and 8 packs / min. For 3 $\mathrm{kg}$ package, rice capable to package 13 packs / minutes, soybeans 8 packs / min and corn 6 packs / min.
\end{abstract}

KATA KUNCI: sensor massa, weighing indikator, pengemasan

\section{PENDAHULUAN}

Teknologi pengemasan berkembang dari waktu ke waktu dan menjadi bagian dari kehidupan masyarakat terutama dalam hubungannya dengan produk pertanian. Seiring de-ngan itu teknologi pengemasan berkembang dengan pesat menjadi bidang ilmu dan teknologi yang semakin canggih. Pembahasan mengenai bidang pengemasan saat ini juga semakin menarik, mulai dari bahan yang bervariasi hingga model atau bentuk dari teknologi pengemasan yang beragam [1].

Teknologi pengemasan di berbagai bidang industri atau yang lebih dikenal dengan industrial handling menggunakan peralatan pengemasan hasil produksi yang berbasis teknologi tinggi dan disebut Packaging Technology. Peralatan ini menerapkan aplikasi dari sensor elektromekanik yang berfungsi untuk mengukur besar gaya statik maupun mekanik yang bekerja padanya [2].

Sensor adalah alat yang dapat menerima rangsangan dan merespon dengan suatu sinyal elektrik. Fungsi dari sensor untuk merespon masukan sifat fisis dan mengkonversikan ke

*E-MAIL: bachtera@physics.its.ac.id dalam sinyal elektrik melalui kontak elektronik. Sensor dapat dikatakan sebagai suatu translator dari besaran non elektrik menjadi besaran elektrik. Elektrik artinya sinyal yang dapat disalurkan, dikuatkan dan dimodifikasi oleh peralatan elektronika. Sinyal keluaran sensor dapat berupa tegangan, arus, frekuensi, fase, atau kode digital [3].

Pada dasarnya sensor dan tranduser mempunyai kesamaan yaitu menerima rangsangan dari luar dan mengubahnya menjadi sinyal listrik. Proses fisis yang merupakan stimulus sensor dapat berupa gaya, arus listrik, temperatur, fluks cahaya, tekanan. Perbedaan antara sensor dan tranduser terletak pada koefisien konversi energi. Sensor terdiri dari tranduser tanpa penguat atau pengolahan sinyal yang terbentuk dalam satu indera [4].

Load Cell terdiri dari satu buah strain gauge atau lebih yang ditempelkan pada batang atau cincin logam. Piranti ini dirancang untuk mengukur gaya tekanan mekanik dan dipasang pada obyek yang akan diberi tekanan mekanik. Ketika obyek terkena tekanan, benang-benang kertas foil akan tertarik memanjang, sehingga menjadi lebih panjang dan tipis yang menyebabkan tahanan listriknya bertambah. Perubahan nilai tahanan ini sangat kecil sehingga diperlukan rangkaian khusus untuk mengukurnya yaitu rangkaian jembatan Wheatstones [5]. 


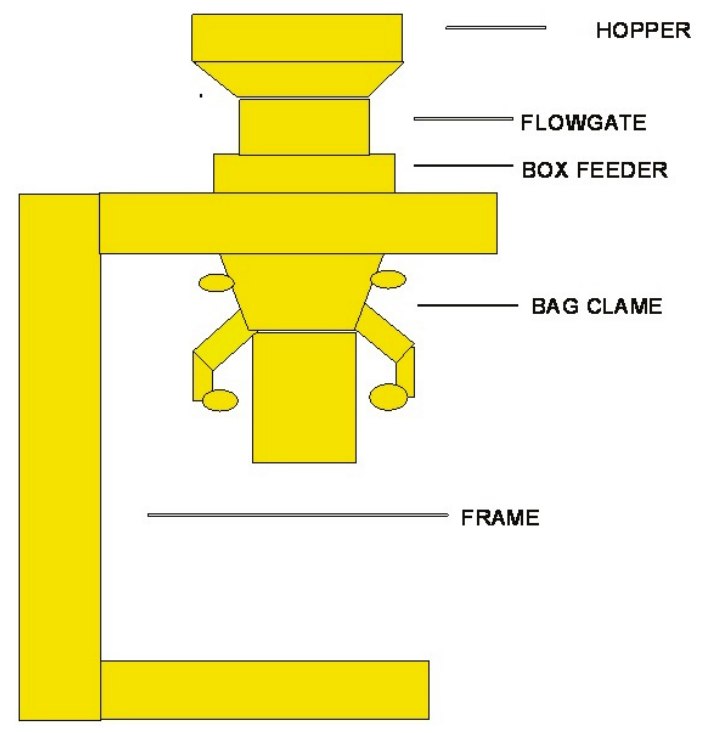

Gambar 1: Kontruksi Peralatan.

\section{METODE PENELITIAN}

Peralatan pengemasan produk hasil pertanian yang dibuat pada penelitian ini terdiri dari:

\section{Konstruksi Alat}

Gambar 1 menunjukkan skema peralatan dengan keterangan sebagai berikut:

1. Penyangga mekanik, terbuat dari pipa besi siku 1,5 yang dibentuk seperti kerangka balok dengan ukuran $830 \mathrm{~cm}$ $\times 470 \mathrm{~cm} \times 615 \mathrm{~cm}$ kemudian dilapisi dengan plat besi setebal $0,8 \mathrm{~mm}$.

2. Bagian hoper, yang merupakan wadah untuk menampung material pertama kali. Artinya sebelum menuju bag clame material yang akan ditimbang harus dimasukkan ke hoper dengan tujuan untuk mengetahui berat material yang akan dikemas.

3. Bagian bag clame, berfungsi untuk menampung hasil timbangan sesuai besar kemasan dan menjepit karung atau plastik yang digunakan sebagai piranti kemasan.

\section{Perangkat Elektronik}

1. Rangkaian Load Cell dan Weighing Indicator

Pada umumnya load cell mempunyai jumlah kabel empat atau enam kabel. Untuk load cell enam kabel selain mempunyai - dan + signal, maupun - dan + excitation juga memiliki jalur - dan + sense. Jalur sense ini tersambung dengan jalur sense indikator yang berfungsi memonitor tegangan aktual pada load cell dan mengirim balik ke indikator untuk dianalisa apakah perlu menambah sinyal yang dikirim balik sebagai konpensasi daya pada load cell. Pada peralatan ini digunakan dua buah

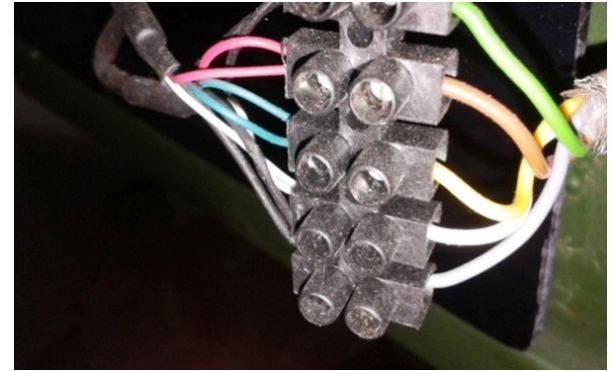

Gambar 2: Rangkaian load cell dan weighing indicator.

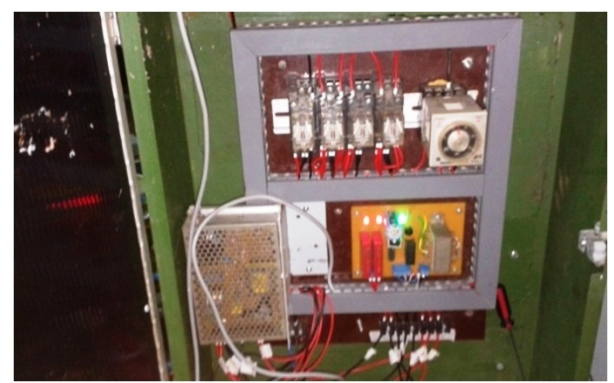

Gambar 3: Rangkaian kontroller.

load cell yang disusun paralel kemudian dirangkaikan pada weighing indicator dengan menggunakan metode jembatan wheatstone. Rangkaian load cell dan weighing indicator ditunjukkan Gambar 2.

2. Rangkaian kontroller

Rangkaian kontroller dengan relay-relaynya (Gambar 3) berfungsi untuk menggerakkan katup-katup yang berada pada box feeder dan bag clame agar bahan uji dapat menuju ke kantong pengemasan. Saat saklar pada switch bag clame dijalankan, arus akan mengalir keseluruh rangkaian dan relay I akan bekerja sehingga kontak yang berada di relay I yang awalnya normally close menjadi normally open. Karena kontak relay I juga menuju ke timer maka kontak timer yang semula normally open berubah menjadi normally close dan selanjutnya solenoid bag clame bekerja untuk melakukan pengemasan.

3. Rangkaian Solenoid dan Pneumatic

Proses penjepitan kantung pengemasan dilakukan dengan menggunakan pneumatic yang dihubungkan dengan solenoid (Gambar 4). Pada pengoperasiannya silinder pneumatik dikontrol oleh katup pengontrol. Katup pengontrol ini berfungsi mengontrol arah udara yang akan masuk ke tabung silinder. Dengan kata lain, katup kontrol arah inilah yang mengontrol gerak maju-mundur piston. Katup kontrol arah ini dikendalikan secara elektrik oleh solenoid, fungsinya sebagai penjepit pengemas setelah terisi sesuai ukuran berat yang diinginkan. 


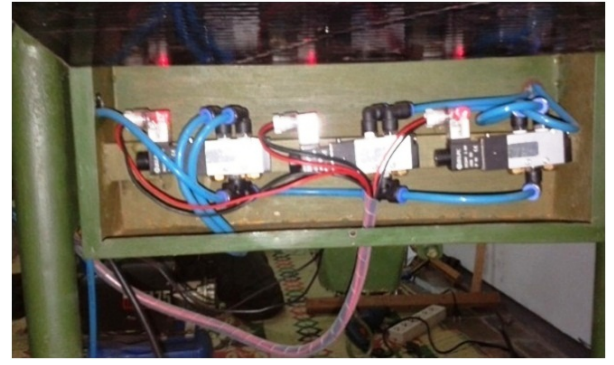

Gambar 4: Rangkaian solenoid dan pneumatic.

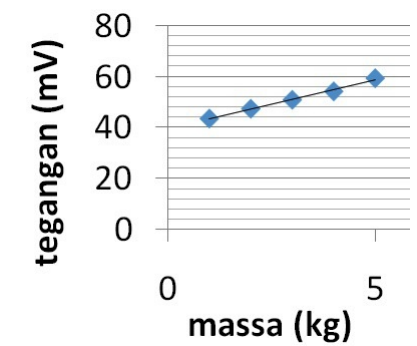

Gambar 5: Grafik kalibrasi load cell.

\section{HASIL DAN PEMBAHASAN}

\section{Kalibrasi}

Sebelum peralatan digunakan untuk pengukuran, telah dilakukan kalibrasi pada load cell dan weighing indicator.

1. Kalibrasi load cell dilakukan dengan non zero calibration pada tegangan dengan tegangan keluaran tidak menunjukkan harga nol ketika beban (anak timbangan) belum diberikan. Hasil kalibrasi seperti terlihat pada grafik dalam Gambar 5.

2. Pada weighing indicator dilakukan dua kali kalibrasi yaitu kalibrani sebelum diberi beban dan kalibrasi setelah diberi beban.

- Kalibrasi sebelum diberi beban

- Pada monitor, tekan kalibrasi maka akan muncul tulisan "cal" pada layar monitor

- Tekan ENTER akan muncul "cal set"

- Tekan ENTER akan muncul "cal 0"

- Tekan ENTER tunggu kurang lebih dua sekon akan muncul "cal SPn"

- Tekan ESC akan muncul "cal set"

- Tekan ESC kembali ke keadaan semula dan kalibrasi selesai

Contoh tampilan weighing indicator setelah dikalibrasi tanpa beban, ditunjukkan dalam Gambar 6 .

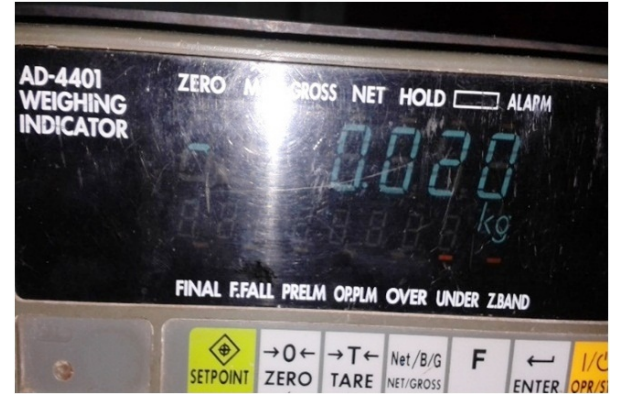

Gambar 6: Weighing indicator setelah dikalibrasi tanpa beban.

- Kalibrasi setelah diberi beban

- Pada monitor, tekan kalibrasi maka akan muncul tulisan "cal" pada layar monitor

- Tekan ENTER akan muncul "cal set"

- Tekan ENTER akan muncul "cal 0"

- Tekan ENTER tunggu kurang lebih dua sekon dan muncul "cal SPn"

- Ganti nilai "cal SPn" sesuai beban yang akan digantung

- Gantung beban

- Tekan ENTER tunggu kurang lebih dua sekon dan muncul "cal end"

- Tekan ESC akan muncul "cal set"

- Tekan ESC kembali ke keadaan semula dan kalibrasi akan sesuai dengan berat beban yang digantung

\section{Hasil Pengukuran Bahan Uji}

Dalam penelitian ini digunakan 3 macam bahan uji hasil pertanian yaitu beras, kedelai, jagung, masing-masing bahan dikemas dalam kemasan $2 \mathrm{~kg}$ dan $3 \mathrm{~kg}$. Hasil pengukuran untuk kemasan $2 \mathrm{~kg}$ diperoleh grafik hubungan waktu pengemasan terhadap jumlah kemasan untuk tiap bahan uji, seperti ditunjukkan Gambar 7.

Pengemasan beras dengan 20 kantong kemasan dibutuhkan waktu pengemasan 71 sekon, untuk 1 kantong kemasan diperlukan waktu 3,56 sekon dan dalam 1 menit dihasilkan 17 kantong kemasan. Pada kedelai dan jagung dibutuhkan waktu 120,37 sekon dan 146 sekon untuk 20 kantong kemasan. Untuk 1 kantong kemasan, diperlukan waktu 6,05 sekon dan 7,36 sekon sedangkan dalam 1 menit dapat dikemas masingmasing 10 kantong dan 8 kantong kemasan. Untuk kemasan $3 \mathrm{~kg}$ diperoleh grafik hubungan waktu pengemasan terhadap jumlah kantong seperti Gambar 8.

Seperti halnya pada kemasan $2 \mathrm{~kg}$, untuk kemasan $3 \mathrm{~kg}$ juga diukur waktu pengemasan untuk 20 kantong (beras butuh waktu 92 sekon, kedelai 153 sekon, jagung 187 sekon), waktu pengemasan untuk 1 kantong (beras 4,8 sekon, kedelai 7,64 sekon, jagung 9,33 sekon) dan jumlah kantong yang 


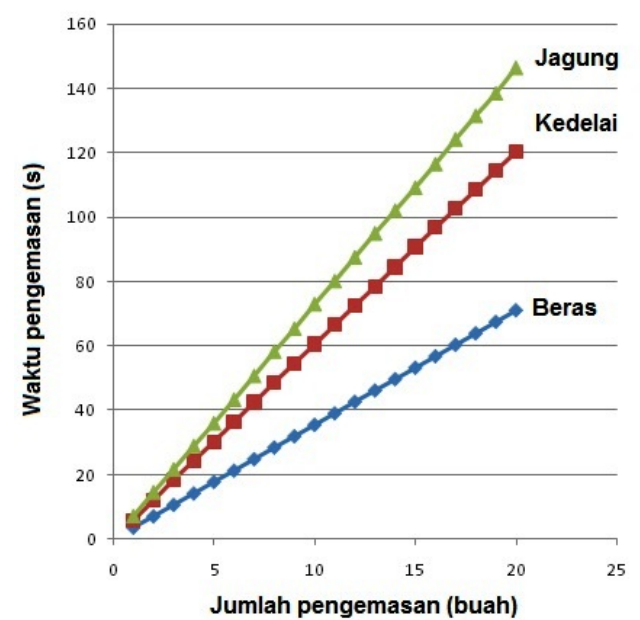

Gambar 7: Grafik waktu pengemasan untuk kemasan 2 kg.

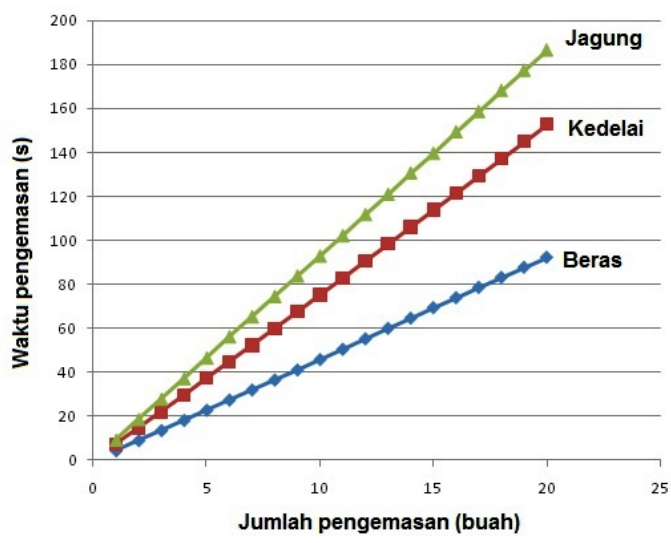

Gambar 8: Grafik waktu pengemasan untuk kemasan $3 \mathrm{~kg}$.

berhasil dikemas dalam kurun waktu 1 menit (beras 13 kantong kemasan, kedelai 8 kantong kemasan, jagung 6 kantong kemasan).

Dari data-data di atas, terlihat jagung memerlukan waktu yang lebih lama untuk dikemas dibandingkan beras dan kede- lai. Hal ini disebabkan butiran-butiran jagung yang besar mengakibatkan sulitnya jagung langsung menuju bag clame untuk dikemas. Butiran-butiran ini menumpuk di box feeder baru selanjutnya secara perlahan akan menuju bag clame. Sebaliknya karena butiran-butiran beras berukuran kecil, maka ketika berada di box feeder akan dengan mudah menuju ke bag clame untuk dikemas.

Pada grafik dalam Gambar 7, bila dilakukan proses ekstrapolasi akan diperoleh data waktu pengemasan untuk 30 kantong kemasan $2 \mathrm{~kg}$ (total massa $60 \mathrm{~kg}$ ) beras memerlukan waktu 107,18 sekon, kedelai 180,74 sekon dan jagung 218 sekon.

Dari data untuk 20 kantong kemasan $3 \mathrm{~kg}$ (total massa $60 \mathrm{~kg}$ ) seperti pada grafik dalam Gambar 8 diperoleh waktu pengemasan beras 92 sekon, kedelai 153 sekon dan jagung 187 sekon. Terlihat bahwa untuk total massa yang sama, kemasan $2 \mathrm{~kg}$ memerlukan kurun waktu yang lebih lama untuk mengemas seluruh massa bahan dibandingkan dengan kemasan $3 \mathrm{~kg}$.

\section{SIMPULAN}

Dari penelitian yang telah dilakukan dapat disimpulkan beberapa hal, antara lain :

1. Mobile Bagging System dengan komponen utamanya menggunakan sensor massa telah dapat dibuat dan bekerja dengan baik

2. Jumlah kantong kemasan yang berhasil dikemas dalam kurun waktu 1 menit adalah: beras 17 kantong, kedelai 10 kantong dan jagung 8 kantong (untuk kemasan $2 \mathrm{~kg}$ ); beras 13 kantong, kedelai 8 kantong, jagung 6 kantong (kemasan $3 \mathrm{~kg}$ ).

3. Untuk total massa yang sama, kemasan $3 \mathrm{~kg}$ memerlukan waktu yang lebih cepat untuk mengemas seluruh massa bahan.
[1] E. Julianti, dan M. Nurminah, Buku Ajar Teknologi Pengemasan (Universitas Sumatra Utara, Medan, 2006).

[2] J. Freden, Handbook of Modern Sensor,Physics,Designs, and Application (Springer, San Diego, 2003).

[3] S.R. Ian, Sensor and Tranduser A Guide for Technicians (Great
Britain, New York, 1988)

[4] O. Bishop, Dasar-dasar Elektronika (Erlangga, Jakarta, 2008).

[5] www.elektronikabersama.web.id./2011/09/sensor-gaya-straingauge-load-cell.html 